\title{
PENERAPAN APLIKASI PENGELOLAAN PENDAPATAN BERBASIS OBJEK PADA KLINIK ALTHA MEDIKA SUKABUMI
}

\author{
Neng Sella Zakiatun Nufus ${ }^{1}$, Renny Oktapiani ${ }^{2}$ \\ 1, 2, 3 Universitas Bina Sarana Informatika \\ e-mail: nengsellazakiatunnufus@gmail.com,renny.rop@bsi.ac.id
}

\begin{abstract}
Abstrak
Klinik Altha Medika merupakan klinik dan rumah bersalin yang memberikan pelayanan medis untuk para pasien. Selama ini sistem yang ada di Klinik Altha Medika dalam pengelolaan data terutama dalam pencatatan pendapatan dari pasien umum masih berupa tulisan tangan dengan menggunakan media kertas yang mudah rusak dan hilang datanya sehingga membutuhkan sistem informasi pendapatan pasien. Pengembangan sistem informasi dalam pembuatan aplikasi menggunakan software yaitu Java Netbeans IDE 8.1 dengan bahasa pemrograman, XAMPP, PHP serta database MySQL. Dengan menggunakan sistem yang terkomputerisasi diharapkan dapat membantu petugas administrasi dalam pengelolaan data seperti pendaftaran pasien, pemeriksaan pasien, transaksi pembayaran, dan pembuatan laporan pendapatan. Sehingga pembuatan laporan pendapatan lebih cepat, akurat, efektif, dan efisien.
\end{abstract}

Kata kunci : Aplikasi, Pendapatan,

\begin{abstract}
Altha Medika Clinic is a clinic and maternity home that provides medical services for patients. So far the existing system at Altha Medika Clinic in data management, especially in recording income from general patients is still in the form of handwriting using paper media that is easily damaged and missing data so that it requires a patient income information system. Development of information systems in making applications using software Java Netbeans IDE 8.1 with programming languages, XAMPP, PHP and MySQL databases. By using a computerized system it is hoped that it can assist administrative staff in managing data such as patient registration, patient examination, payment transactions, and making income reports. So that making income reports is faster, more accurate, effective, and efficient.
\end{abstract}

Keywords: Aplication, Income,

\section{Pendahuluan}

Pada saat ini perkembangan teknologi dan informasi yang berasis IT sangat pesat dan semakin dikenal luas oleh masyarakat umum, mulai dari media informasi yang awalnya hanya digunakan pada media kertas, sekarang berpindah ke media komputerisasi. Hampir di semua perusahaan, organisasi, lembaga, rumah sakit dan instansi pemerintahan memerlukan pengelolaan data dan informasi yang cepat, tepat dan akurat dalam meningkatkan kinerjanya, salah satunya klinik yang di dalamnya juga terdapat pengelolaan informasi (Rozaq, Shintia, Harmini, \& Saraswati, 2017).

Klinik adalah salah satu tempat penyelenggaraan kegiatan yang dimanfaatkan untuk memberikan jasa pelayanan medis yang dibutuhkan bagi setiap pasien. Klinik merupakan suatu bentuk perusahaan jasa yang dikelola oleh pemerintah maupun pihak swasta yang bertujuan memberikan pelayanan kesehatan bagi masyarakat. Untuk memberikan pelayanan pada masyarakat dengan baik, harus didukung oleh penyelenggaraan sistem akuntansi yang baik 
pula (Nuryanti \& Santoso, 2017).

Selama ini operasional pelayanan dalam pendaftaran pasien pada Klinik Altha Medika masih manual. Dalam menyajikan jasa pelayanan kesehatan, pendapatan yang di peroleh Klinik Altha Medika berasal dari penerimaan rawat jalan dan penerimaan rawat inap. Pada pelayanannya terdapat empat proses pelayanan pasien rawat jalan yang diberikan oleh Klinik Altha Medika, yaitu proses pendaftaran pasien, proses pemeriksaan medis, proses pembayaran dan proses pembuatan laporan pendapatan.

Dalam menjalankan proses bisnisnya saat ini, pada saat pendaftaran pasien, petugas harus menginput data pasien yang berkunjung setiap harinya. Pada bagian pemeriksaan dokter/bidan harus mencatat data diagnosa penyakit pasien dan resep obat pada buku rekam medis. Pada pembayaran pemeriksaan, petugas apoteker merancik obat sesuai resep dan memberikan total pembayaran pemeriksaan kepada petugas administrasi. Sedangkan pada pencatatan pendapatan kas masuk pembayaran pemeriksaan dari pasien umum rawat jalan masih berupa tulisan tangan dengan menggunakan media kertas yang data nya mudah rusak dan hilang, hal ini akan memperlambat dalam pembuatan laporan pendapatan yang nanti nya akan di laporkan pada manager. Dari uraian diatas diperlukan suatu rancangan sistem informasi komputerisasi yang lebih efektif untuk menunjang pelayanan kepada masyarakat yang lebih baik, dan untuk mempermudah petugas dalam melakukan pekerjaannya.

\section{Metode Penelitian}

\section{a. Metode pengumpulan data}

Untuk memperoleh data yang akurasi dan relevan penulis melakukan teknik pengumpulan data yaitu:

1) Observasi

Dalam hal ini penulis melakukan observasi atau pengamatan langsung pada Apotik Zam-zam.

2) Wawancara

Adalah komunikasi dua arah untuk mendapatkan data dari responden yang dapat dipercaya sebagai masukan untuk melengkapi penelitian ini.

3) Studi Pustaka

Studi Pustaka yang dilakukan,yaitu dengan mempelajari serta mengumpulkan teori-teori yang relevan dengan topik yang dibahas guna memperoleh data serta informasi tertulis yang berhubungan dengan masalah yang dikemukakan.

\section{b. Metode Pengembangan Sistem}

Proses pengembangan perangkat lunak (Sofware Development Process) adalah suatu penerapan struktur pada pengembangan suatu Perangkat Lunak (Software), yang bertujuan untuk mengembangkan sistem dan memberikan panduan untuk menyukseskan proyek pengembangan sistem melalui tahapan-tahapan tertentu.

Model pengembangan sistem yang digunakan adalah Model Sekuensial Linier (Waterfall Development Model) dengan menggunakan sebuah pendekatan perkembangan perangkat lunak yang berurutan serta sekuensial, dimulai dari tingkat dan kemajuan sistem pada seluruh tahapan analisis, desain, kode, pengujian dan pemeliharaan. Tahapan-tahapan untuk Pengembangan Model Sekuensial Linear (Waterfall Development Model) yaitu:

1. Rekayasa dan Pemodelan Sistem/Informasi

Rekayasa dan pemodelan sistem/informasi merupakan langkah pertama untuk membangun seluruh sistem elemen sistem serta memilih bagian yang akan dijadikan bahan pengembangan perangkat lunak, dengan memperhatikan hubungannya dengan Hardware,User, dan Database. Pemodelan sistem ini menggunakan hardware berupa PC (personal computer) dan database yang dibuat menggunakan MySQL.

2. Analisis Kebutuhan Perangkat Lunak

Analisis kebutuhan perangkat lunak dilakukan untuk menganalisa dan pengumpulan kebutuhan sistem yang meliputi domain informasi. Hasil tersebut didokumentasikan lalu diperhatikan kembali kepada pelanggan. Perangkat lunak yang digunakan berupa aplikasi Java Netbeans IDE 8.1.

\section{Desain}

Proses ini dilakukan untuk penerjemahan syarat kebutuhan suatu perancangan perangkat lunak yang telah diperhatikan sebelum dibuat proses pengkodean (coding). Desain sistem yang akan dibuat menggunakan UML (Unified Modelling Language), ERD (Entity Relational Diagram), LRS (Logical Relational Structure). Adapun desain sistem menggunakan aplikasi Enterprise Architect 12.1.

4. Pengkodean

Pengkodean yaitu proses untuk 
menterjemahkan suatu rancangan desain dalam bentuk yang mudah dimengerti oleh mesin, dengan menggunakan bahasa pemrograman.

5. Pengujian

Proses pengujian pada program perangkat lunak dilakukan untuk memeriksa segala kemungkinan terjadinya kesalahan dan apakah hasil dari pengembangan tersebut sesuai dengan apa yang diinginkan.

6. Pemeliharaan

Proses pemeliharaan merupakan bagian paling akhir dari siklus pengembangan dan dilakukan setelah perangkat lunak dipergunakan.

\section{Hasil dan Pembahasan}

\subsection{Analisa Kebutuhan}

Berdasarkan proses sistem usulan pada Klinik Altha Medika, maka tahapan berikutnya adalah analisis kebutuhan. Berikut ini spesifikasi kebutuhan (System Requirement) dari sistem pengobatan rawat jalan pada Klinik Altha Medika.

Halaman Admin:

a. Admin dapat melakukan Login

b. Admin dapat mengelola data pasien

c. Admin dapat mengelola data pemeriksaan

d. Admin dapat mengelola data Dokter

e. Admin dapat mengelola data perkiraan

f. Admin dapat mengelola transaksi pembayaran

g. Admin dapat mengelola transaksi jurnal

h. Admin dapat mengelola laporan pendapatan

i. Admin dapat mengelola laporan data pasien

j. Admin dapat mengelola laporan pemeriksaan

k. Admin dapat mengelola laporan jurnal

I. Admin dapat melakukan logout

\subsection{Desain}

Untuk memberikan gambaran yang jelas tentang sistem yang dibangun dibutuhkan rancangan sistem informasi, rancangan database, antar muka untuk memudahkan dalam proses implementasi sistem.

\section{a. Desain Sistem}

Desain sistem informasi penjualan obat disajikan dengan menggunakan usecase dan disesuaikan kebutuhan sistem.

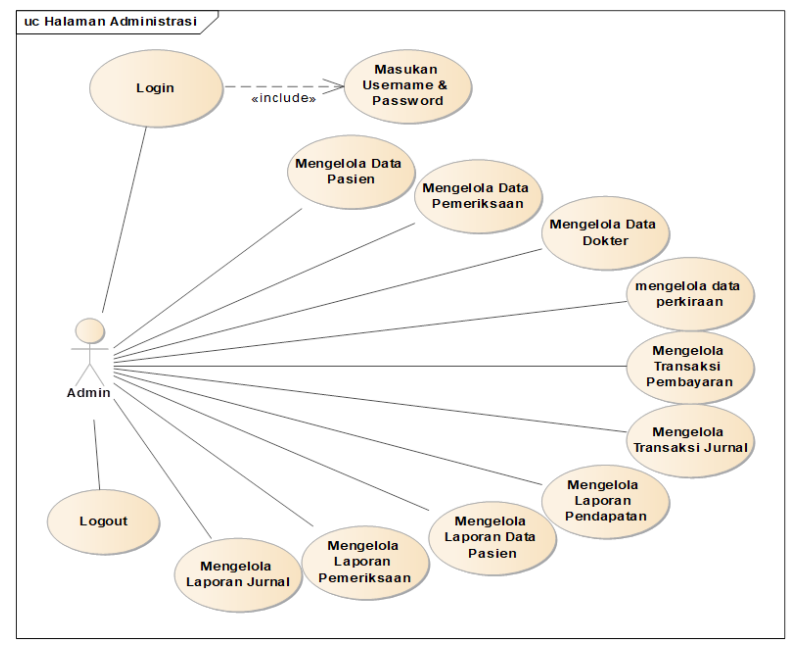

Gambar 1. Usecase Diagram

Sumber : Olahan Peneliti (2019) 
JURNAL SWABUMI, Vol. 7 No.1 Maret 2019, pp. 54 61

ISSN: 2355-990X

E-ISSN:2549-5178

b. Desain ERD (Entity Relationship Diagram)

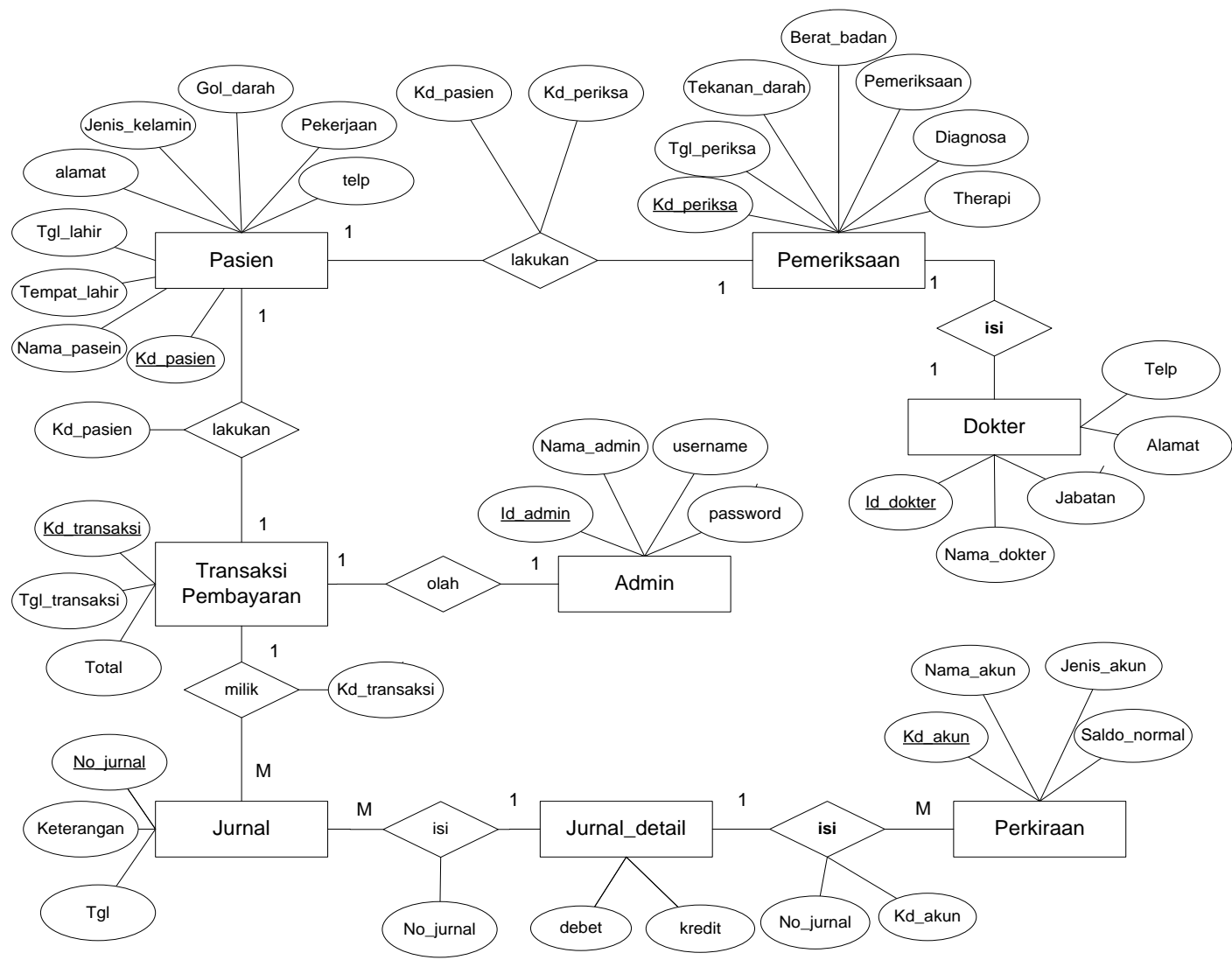

Gambar 2. ERD (Entity Relational Diagram)

Sumber : Sumber : Olahan Peneliti (2019) 
JURNAL SWABUMI, Vol. 7 No.1 Maret 2019, pp. 54 61

ISSN: 2355-990X

E-ISSN:2549-5178

c. Logical Record Structure (LRS)

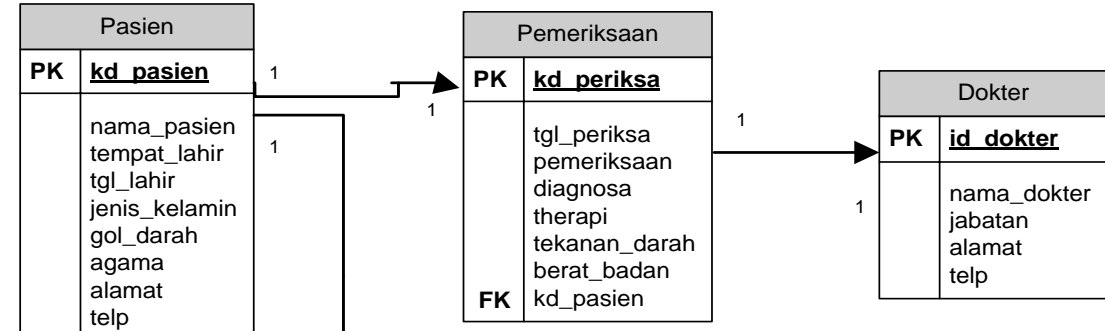
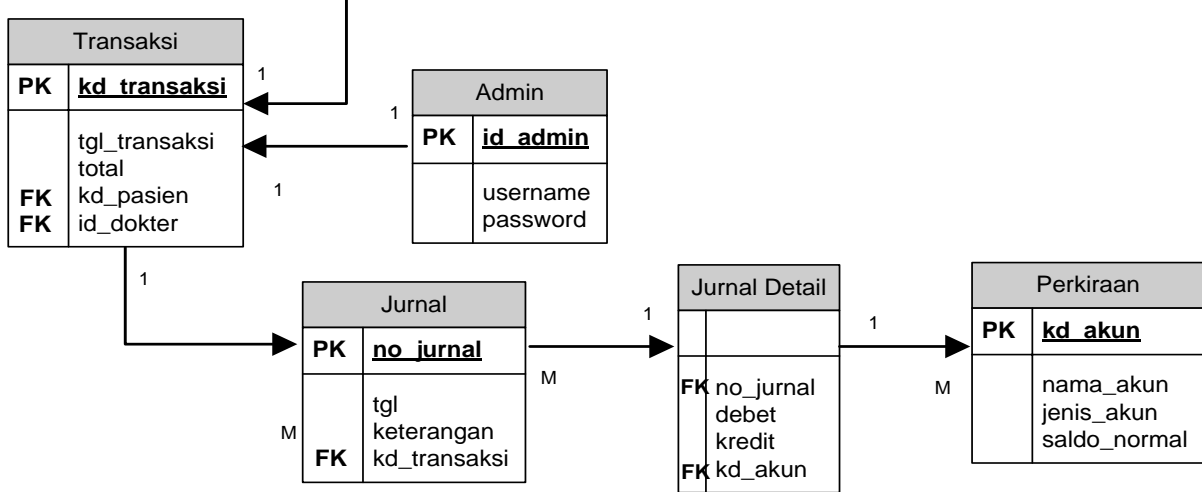

Gambar 3. Logical Record Structure (LRS)

Sumber : Sumber : Olahan Peneliti (2019)

d. Sequence Diagram Transaski Jurnal

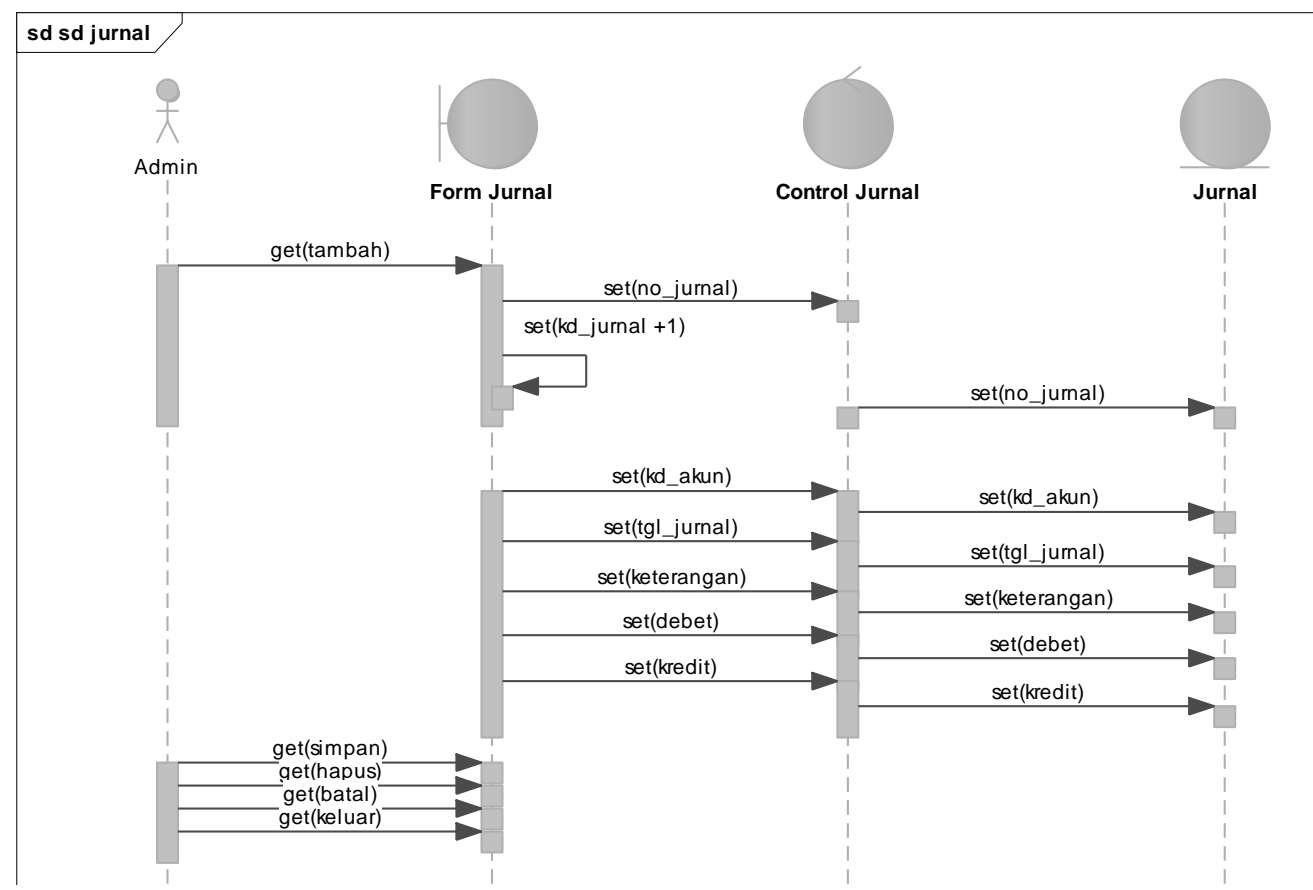

Gambar 4. Sequence Diagram Transaski Jurnal

Sumber : Sumber : Olahan Peneliti (2019) 


\section{e. Deployment Diagram}

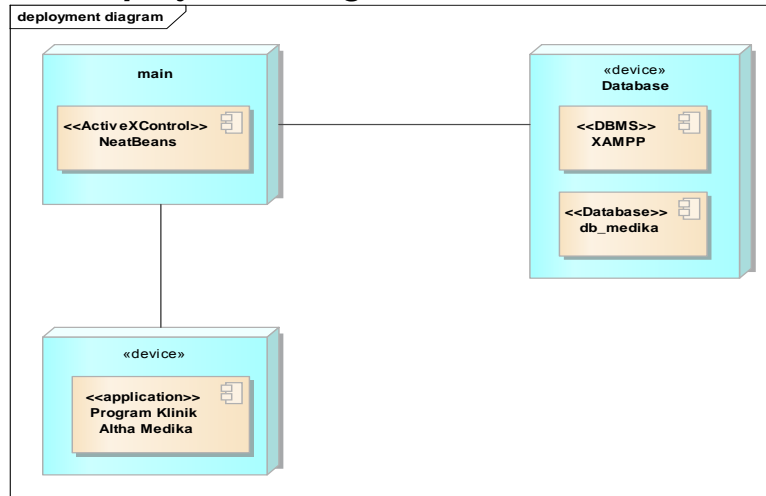

f. User Interface

\section{1) Halaman Login}

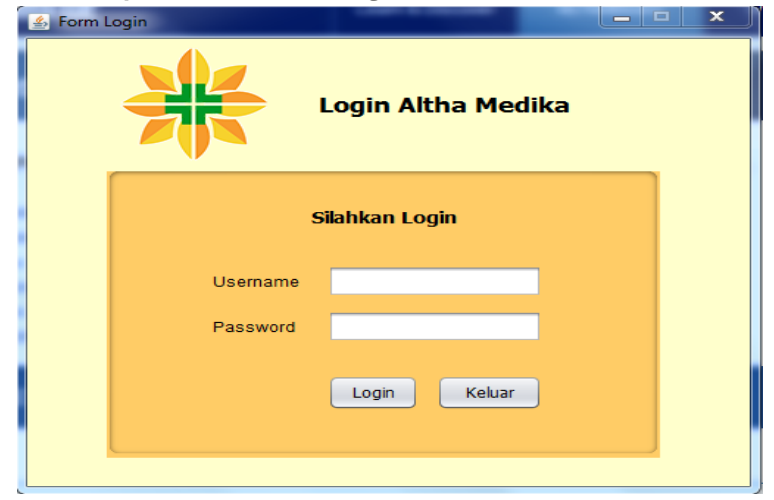

Gambar III.27. User Interface Halaman Login

2) Menu Utama

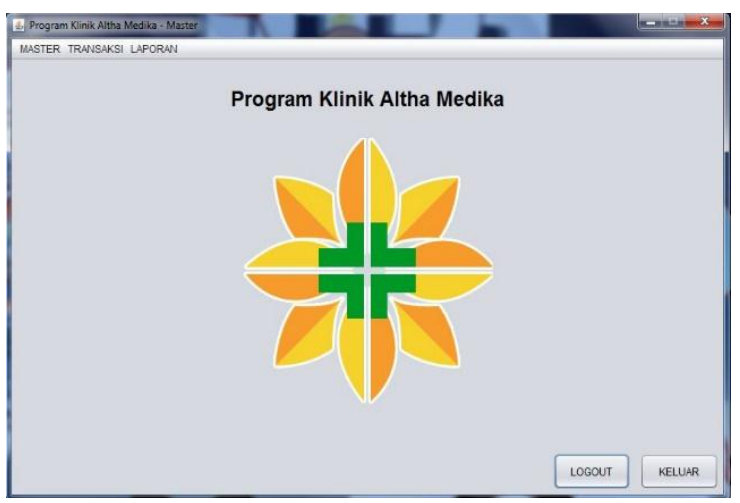

Gambar III.28. User Interface Menu Utama
3) Form Master Data Pasien

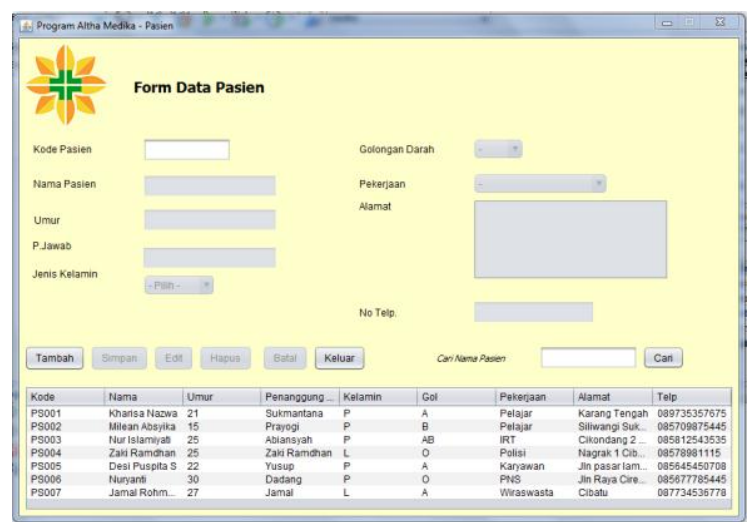

Gambar III.29. User Interface Data Pasien

4) Form Master Data Pemeriksaan

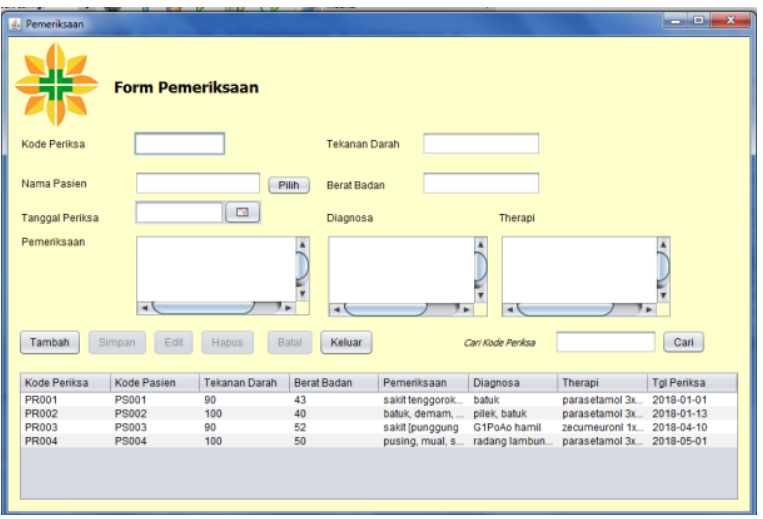

Gambar III.30. User Interface Data Pemeriksaan

5) Form Master Data Dokter

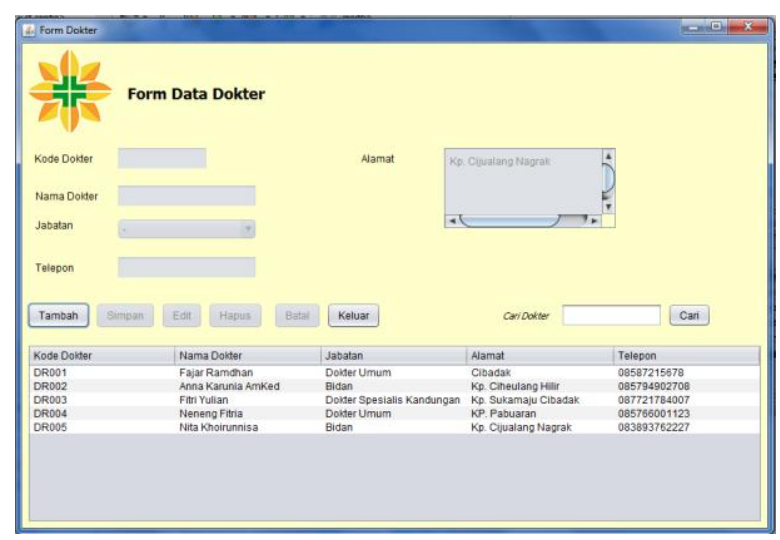

Gambar III.31. User Interface Data Dokter 
6) Form Master Data Perkiraan

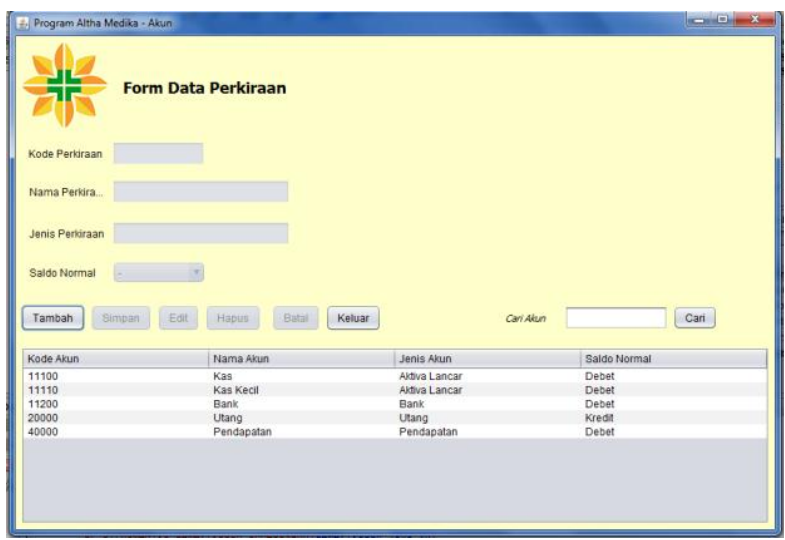

Gambar III.32. User Interface Data Perkiraan

\section{7) Form Transaksi Pembayaran}

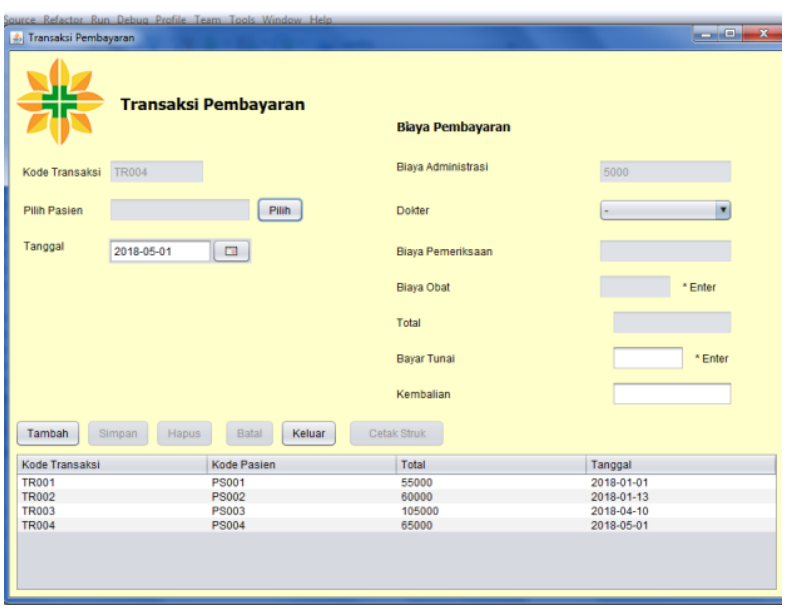

Gambar III.33. User Interface Transaksi Pembayaran
8) Form Transaksi Jurnal

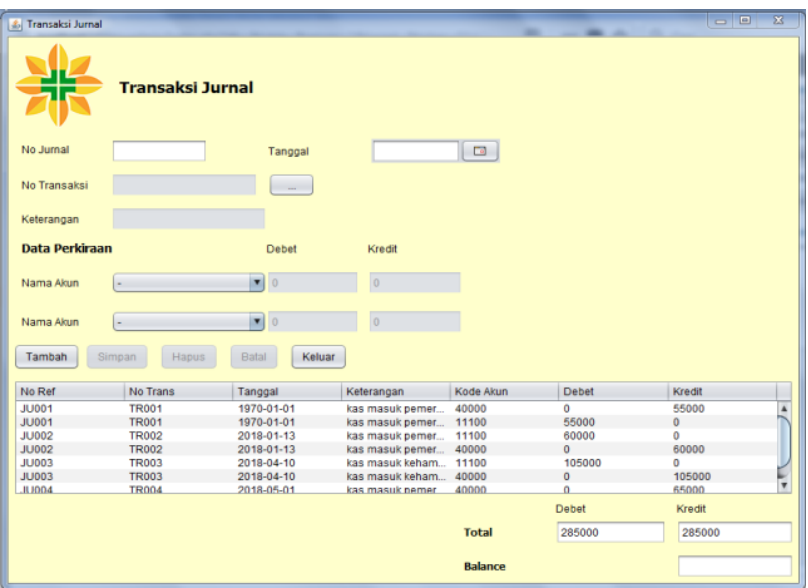

Gambar III.34. User Interface Transaksi Jurnal

9) Laporan Pendapatan

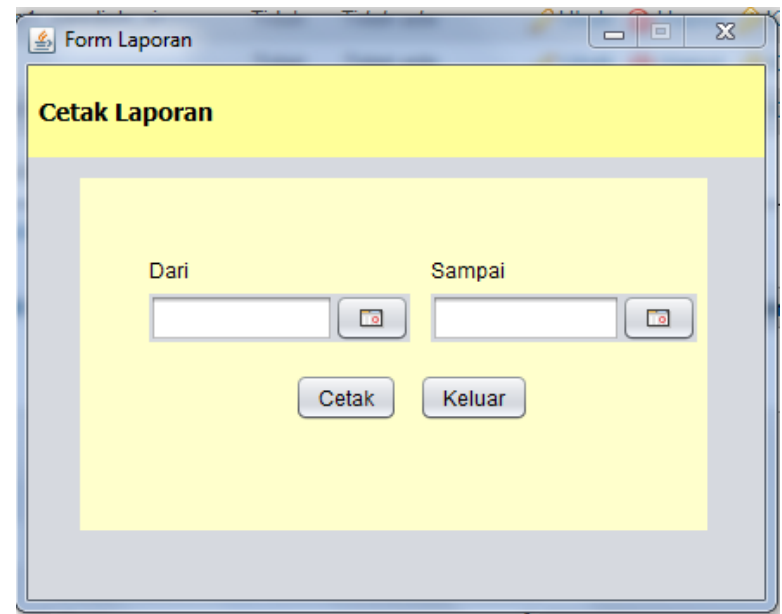

Gambar III.35. User Interface Laporan Pendapatan 


\subsection{Pengkodean}

Komponen perangkat lunak adalah serangkaian unsur-unsur yang terdiri dari beberapa perangkat lunak program komputer yang digunakan untuk membantu proses kerja manusia (brainware). Berikut ini rancangan spesifikasi software usulan pada Klinik Altha Medika DBMS menggunakan My SQL Server dan bahasa Pemograman yaitu Java NetBeans IDE 8.1.

\subsection{Pengujian}

Untuk tahap pengujian atau testing, penulis menggunakan pengujian dengan metode blackbox, dimana pengujiannya dilakukan pada tampilan program apakah program dapat berjalan dengan baik sesuai yang diinginkan.

\section{Simpulan}

Berdasarkan uraian-uraian yang telah disampaikan pada bab-bab sebelumnya, dapat ditarik simpulan bahwa:

Sistem yang berjalan di Klinik Altha Medika selama ini belum menghasilkan informasi yang optimal mengenai pendataan, transaksi pembayaran dan proses pembuatan laporan, sehingga diperluka sebuah sistem yang dapat memberikan informasi yang lebih optimal, serta dapat mempermudah dan mempercepat kinerja karyawan.

Dengan adanya Rancangan Sistem Informasi Pendapatan Pasien Umum Pada Klinik Altha Medika Sukabumi yang dibuat, dapat diterapkan dengan baik, dan diharapkan dapat membantu petugas administrasi dalam mengelola seluruh data, serta dapat mengatasi permasalahan yang ada selama ini untuk meningkatkan pelayanan kepada masyarakat.

Dengan proses yang sudah terkomputerisasi dapat mempercepat pengelolaan data pada pembuatan laporan khususnya laporan pendapatan, serta dapat menghasilkan informasi yang lebih akurat, cepat, dan efisien.

\section{Referensi}

Arifin, Z. (2014). Akuntansi Penjualan Pada Perusahaan $\mathrm{Pt}$. Purana Parasindo. Jurnal Informatika Mulawarman, 7(1), 12-22.

Ernawati. (2014). EVALUASI SISTEM
PENGELOLAAN PENDAPATAN

RAWAT INAP PADA RUMAH SAKIT

UMUM DAERAH ULIN

BANJARMASIN, 10(4), 269-285.

Hery. (2014). Pengendalian Akuntansi dan Manajemen. Jakarta: Kencana.

Mardi. (2014). Sistem Informasi Akuntansi. Bogor: Ghalia Indonesia.

Mustakini, J. H. (2014). Analisa dan Desain Sistem Informasi. Yogyakarta: Andi Offset.

Nena, A. F. D. (2015). Analisa Sistem Informasi Akuntansi Dalam Meningkatkan Pengendalian Internal Atas Pendapatan Di Rumah Sakit Hermana-Lembean. Analisa Sistem Informasi Akuntansi, 3(4), 117-129.

Nuryanti, Y., \& Santoso, S. (2017). EVALUASI SISTEM INFORMASI AKUNTANSI PENERIMAAN KAS STUDI KASUS PADA KLINIK BERSALIN DEVALISHA Yuni Nuryanti 1) ,Sugeng Santoso 2) 1). Jurnal Penelitian dan Kajian Ilmiah Fakultas Ekonomi Universitas Surakarta ISSN, 15(3), 72-80. https://doi.org/10.2311/.V15I3.1866

Prastika, M. R. (2015). Sistem Informasi Rekapitulasi Pendapatan Pada Puskesmas Pembantu Sidomulyo. Journal Speed - Sentra Penelitian Engineering dan Edukasi, 7(1), 59-64.

Rozaq, A., Shintia, N., Harmini, Y., \& Saraswati, N. (2017). Sistem informasi pemeriksaan pasien klinik. Jurnal ELTIKOM, 1(1), 39-46. Diambil dari http://eltikom.poliban.ac.id/index.php/elti kom/article/view/16

Sujarweni, V. W. (2015). Sistem Akuntansi. Yogyakarta: Pustaka Baru Press.

Wongso, F. (2015). Jurnal Ilmiah Ekonomi dan Bisnis. Jurnal Ilmiah Ekonomi dan Bisnis, 12(1), 46-60. 